\title{
Prediction of the in vivo Body Composition of Pigs Based on Cross- Sectional Region Analysis of Dual Energy X-Ray Absorptiometry (DXA) Scans ${ }^{1}$
}

\begin{abstract}
Summary
The purpose of this study was to evaluate the use of a cross-sectional scan as an alternative to the total body DXA scan for predicting the body composition of pigs in vivo. A total of 212 pigs (56 to $138 \mathrm{~kg}$ live body weight) were scanned by DXA. The DXA scans were analyzed for percentage fat and lean in the total body and in 14 cross-sections (57.6 mm wide): 5 in the front leg/thoracic region, 4 in the abdominal region, and 5 in the back leg region. Regression analysis was used to compare total body and cross-sectional DXA results and chemical analysis of total body fat, protein and water. The relation $\left(\mathrm{R}^{2}\right)$ between the percentage fat in individual slices and the percentage of total body fat measured by DXA ranged from 0.78 to 0.97 and by chemical analysis from 0.71 to 0.85 , respectively. The relation between the percentage of lean in the individual slices and chemical analysis for percentage of total body protein and water ranged from 0.48 to 0.60 and 0.56 to 0.76 , respectively. These results indicate that total body composition of the pig can be predicted (accurately) by performing a time-saving single-pass cross-sectional scan.
\end{abstract}

Key Words: pigs, body composition, dual energy X-ray absorptiometry, DXA

\section{Zusammenfassung}

Titel der Arbeit: Schätzung der In-vivo-Körperzusammensetzung von Schweinen anhand regional definierter Querschnitte von Scans aus der Dualenergie-Röntgenabsorptiometrie

Mit Hilfe dieser Studie sollte untersucht werden, ob regional definierte Querschnitte (Scanbereiche) aus der Dualenergie-Röntgenabsorptiometrie (DXA) eine Alternative zum Ganzkörperscan für die Schätzung der Invivo-Körperzusammensetzung beim Schwein bieten könnten. Insgesamt wurden 212 Schweine (56 to $138 \mathrm{~kg}$ Lebendmasse) mittels DXA untersucht. Die DXA-Scans wurden auf den prozentualen Fett- und Magergewebegehalt des gesamten Tierkörpers und in 14 regional definierten Querschnitten (Weite jeweils 57,6 mm) untersucht: 5 Querschnitte in der Schulter-/Thorax-Region, 4 Querschnitte in der Abdominal-Region und 5 Querschnitte in der Hintergliedmaßen-/Schinken-Region. Eine Regressions-Analyse diente dem Vergleich von Ganzkörper- und Regional-Ergebnissen aus der DXA-Analyse bzw. dem Vergleich zu den chemisch ermittelten Gehalten (\%) an Fett, Protein und Wasser des gesamten Tierkörpers. Die Beziehungen ( $\mathrm{R}^{2}$ ) zwischen dem DXAFettgehalt (\%) in einzelnen Querschnitten und dem gesamten Tierkörper variierten zwischen 0,78 und 0,97, während die Beziehungen $\left(\mathrm{R}^{2}\right)$ zwischen dem DXA-Fettgehalt (\%) in einzelnen Querschnitten und dem Gesamtkörperfett (\%) aus der chemischen Analyse zwischen 0,71 und 0,85 lagen. Die Beziehungen $\left(\mathrm{R}^{2}\right)$ zwischen dem DXA-Magergewebegehalt (\%) in einzelnen Querschnitten und den Ergebnissen der chemischen Analyse für das Gesamtkörper-Protein (\%) bzw. für das Gesamtkörper-Wasser (\%) rangierten zwischen 0,48 und 0,60 bzw. zwischen 0,56 und 0,76. Diese Ergebnisse demonstrieren, dass die In-vivo-Ganzkörperzusammensetzung eines Schweines anhand eines einzelnen, regional definierten DXA-Querschnitt-Scans mit hoher Genauigkeit geschätzt werden kann, ohne einen zeitaufwendigen Ganzkörper-Scan durchführen zu müssen.

Schlüsselwörter: Schwein, In-vivo-Körperzusammensetzung, Dualenergie-Röntgen-Absorptionsmessung, DXA

\footnotetext{
${ }^{1}$ Mention of a trade name does not constitute a guarantee or warranty by the USDA and does not imply its approval to the exclusion of other products that may be suitable.
} 


\section{Introduction}

The use of dual energy X-ray absorptiometry (DXA) to measure the body composition of large animals in vivo is limited by the design of existing equipment. The equipment that is commercially available was designed and constructed for human subjects in a clinical setting where the patient will lie passively in lateral recumbence while being scanned.

By anesthetizing the pig, DXA can be used to measure composition of pigs by performing a total body scan (MITCHELL et al., 1996a, b). The DXA scan can be analyzed for total or regional fat, lean, and bone mineral content. Studies have shown that the results of total body DXA scans of pigs can be used to accurately predict total body fat and that the lean component can be used to predict total body protein and water (MITCHELL et al., 1998). An alternative approach might rely on a rapid crosssectional scan. The fat and muscle areas (or volumes) of cross-sectional images generated by magnetic resonance imaging (MRI) are highly correlated with the total body composition of pigs (FOWLER et al., 1992; BAULAIN et al., 1996, MITCHELL et al., 2001) - as are cross-sectional images generated by x-ray computer tomography (HORN et al., 1997, see review by SZABO et al., 1999) or post mortem by Video Image Analysis (BRANSCHEID et al., 1995). Chemical analysis of cross-sections of pork carcasses has been shown to correlate highly with the composition of the total carcass (DOORNENBAL, 1972). Similarly, analysis of cross-sectional regions of DXA scans of pork half-carcass can be used to predict total carcass fat and lean with an accuracy equivalent to that of the complete scan of the half-carcass (MITCHELL et al., 2002).

The purpose of this study was to determine the feasibility of predicting total body composition of the live pig based on a single cross-sectional measurement.

\section{Materials and Methods}

A total of 212 pigs (56 to $138 \mathrm{~kg}$ live body weight) originating from a variety of crossbred lines (three cross-bred lines) were scanned by DXA. Diet was withheld for approximately 16 hours prior to scanning. Immediately prior to scanning each pig was weighed on an electronic scale $( \pm 0.2 \mathrm{~kg})$. All pigs were anesthetized (500 mg ketamine, $80 \mathrm{mg}$ tiletamine, $80 \mathrm{mg}$ zolazepam and $333 \mathrm{mg}$ xylazine per $100 \mathrm{~kg}$ body weight, i.m., followed by $290 \mathrm{mg}$ ketamine, $37 \mathrm{mg}$ tiletamine, $37 \mathrm{mg}$ zolazepam, 150 $\mathrm{mg}$ xylazine, $3 \mathrm{mg}$ butorphanol tartrate and $0.16 \mathrm{mg}$ atropine sulfate per $100 \mathrm{~kg}$ body weight, i.v.), to prevent movement during the scanning procedure. Total body DXA scans were performed using a Lunar DPX-L (Madison, WI) instrument. The pig was positioned on its stomach with back legs extended and the front legs placed back along the side, but slightly away from the body. Two different scan modes were used as determined by the size of the pig: $30-69 \mathrm{~kg}$, adult-medium; > $69 \mathrm{~kg}$, adult-slow. The scan mode determines the scan speed and/or collimation, but does not affect the x-ray energy level.

The DXA scans were analyzed for percentage fat and lean in the total body. A manual region-of-interest (ROI) analysis was performed for 14 cross-sectional regions (57.6 mm wide) as illustrated in Figure 1. Consecutive slices were constructed in the caudal direction, five in the front leg/thoracic region, starting at the first rib (S 1-6); four in the abdominal region, starting at the last rib (L 1-3); and five in the back leg region, 
starting at the tuber sacrale portion of the ilium (H1-5). Each of these cross-sectional slices was analyzed as an individual ROI for fat and lean content. The fat or lean content of the cross-sectional slice was expressed as a percentage of the total soft tissue within the slice.

After the final series of scans, each pig was euthanized by a lethal injection of pentobarbital. The head and viscera were removed and the carcass was split at the midline. The right half of the carcass was ground and then analyzed for lipid (chloroform/methanol extraction by the method of FOLCH et al., 1957), protein (Kjeldahl N • 6.25; AOAC, 1984), and water (weight loss following 10 day lyophillization). The composition of the right and left-halves were assumed to be equal, therefore, the results of the analysis of the right half were doubled to yield the total for the carcass. The head and viscera were combined, ground and analyzed as above for the carcass.

Where indicated, the DXA fat measurements based on total body scans, were adjusted to correct for previously reported inaccuracy in DXA fat values using the following formula: DXA corrected \% fat $=493.4-348.8$ [R value], where the $\mathrm{R}$ value is the DXA soft tissue attenuation ratio. DXA does not provide a direct measure of either muscle mass or protein content, but rather lean tissue, which is a composite of many components, exclusive of fat and bone mineral. Furthermore, the lean tissue measurement based on chemical analysis was calculated as the sum of water and protein.

Statistical analysis was performed using Statgraphics ${ }^{\circledR}$ Plus for Windows 2.1. Linear regression analysis was used to compare the DXA measurements of fat and lean percentages in the total carcass with those of the various regions and to compare DXA results with chemical analysis. In addition, a stepwise analysis was performed in order to calculate the best combination of single cross-sectional slices to estimate the whole body composition. Differences between means were evaluated by analysis of variance followed by a multiple range test (Fisher’s 95\% LSD).

\section{Results and Discussion}

The DXA instrument used in this study utilized the pencil-beam x-ray technology, scanning at cross-sectional intervals of $9.6 \mathrm{~mm}$ at a scan speed of $7.68 \mathrm{~cm} / \mathrm{second}$. Typically DXA instruments scan at rates of 4 to $16 \mathrm{~cm}$ per second. With these units the subject remains stationary and the scan speed is determined by the simultaneous motor-driven movement of the X-ray source and detector. Newer DXA instruments utilize a wide-angle or fan-beam technology that will scan wider sections. For example the GE-Lunar Prodigy ${ }^{\mathrm{TM}}$ model utilizes the wide-angle technology to produce an effective beam width of $18.3 \mathrm{~mm}$ that is $56 \mathrm{~mm}$ wide by the time it reaches the detector and the Hologic QDR-4500 ${ }^{\mathrm{TM}}$ utilizes the fan-beam technology to produce an effective beam width of $13 \mathrm{~mm}$ that is $260 \mathrm{~mm}$ when it reaches the detector(s). The effective beam width is width of the $\mathrm{x}$-ray beam at $10 \mathrm{~cm}$ above the top of the scan table, while the detector is approximately $45 \mathrm{~cm}$ above the top of the scan table. Comparative studies indicate that the pencil and wide-angle beam are comparable for measuring soft tissue composition (NORD et al., 2000). Therefore, in the present study, $57.9 \mathrm{~mm}$ wide cross-sectional regions were analyzed (representing 6 x $9.6 \mathrm{~mm}$ scan lines) in order to approximate the information that might be obtained in a single 
slice using the wide-angle or fan-beam technology, which was not available for the present study.

The DXA measurement for the distribution of the percentage of fat in the soft tissue of the various cross-sectional slices of the pigs is shown in Table 1. The locations of the individual slices are shown in Figure 1. Among the slices, the highest fat content was in S1 (24.72\%) and the lowest was in L3 (16.39\%). The DXA measurement of the percentage of fat in the entire body $(21.29 \%)$ was less $(p<0.05)$ than that determined by chemical analysis (23.98\%). There was no difference in the fat content predicted from the DXA measurement using a previously reported prediction equation (MITCHELL et al., 1996b) and that determined by chemical analysis. The closest agreement between a DXA cross-sectional slice analysis and DXA total body fat analysis was in the shoulder region (21.68\% for S4, compared to $21.29 \%$ for total body).

\section{Table 1}

Distribution of the dual energy x-ray absorptiometry (DXA) measurement of the percentage of fat in the soft tissue of cross-sectional slices and DXA and chemical measurements of composition of the entire body (Verteilung der Dualenergie-Röntgenabsorptiometrie- [DXA-] Messwerte des prozentualen Fettgehaltes im Weichgewebe von regional definierten Querschnitten sowie DXA- und chemische Messwerte der Körperzusammensetzung des gesamten Tierkörpers)

\begin{tabular}{ll}
\hline Region or slice $^{1}$ & Percentage fat $^{2}$ \\
\hline Slice & \\
S1 & $24.72 \pm 8.30^{\mathrm{a}}$ \\
S2 & $23.59 \pm 8.24^{\mathrm{ab}}$ \\
S3 & $22.96 \pm 8.04^{\mathrm{bc}}$ \\
S4 & $21.68 \pm 7.79^{\mathrm{cd}}$ \\
S5 & $20.89 \pm 7.99^{\mathrm{d}}$ \\
L1 & $17.54 \pm 7.13^{\text {fgh }}$ \\
L2 & $16.99 \pm 7.01^{\text {gh }}$ \\
L3 & $16.39 \pm 6.97^{\mathrm{h}}$ \\
L4 & $16.50 \pm 6.90^{\mathrm{h}}$ \\
H1 & $19.44 \pm 6.86^{\mathrm{e}}$ \\
H2 & $18.19 \pm 6.88^{\mathrm{efg}}$ \\
H3 & $18.38 \pm 6.95^{\mathrm{ef}}$ \\
H4 & $17.93 \pm 6.41^{\mathrm{fg}}$ \\
H5 & $21.89 \pm 8.33^{\mathrm{cd}}$ \\
Total Body & \\
DXA & $21.29 \pm 7.09^{\mathrm{d}}$ \\
DXA, predicted &
\end{tabular}

${ }^{1}$ See Figure 1 for locations.

${ }^{2}$ Means \pm SD followed by different superscript were different at $\mathrm{P}<0.05$ (multiple range test).

${ }^{3}$ Fat $(\%)=493-(349 \times$ DXA R value $)$

The DXA measurements of the percentage of fat in the soft tissue of each of the 14 individual slices were closely related $\left(\mathrm{R}^{2}=0.777\right.$ to 0.966$)$ with the DXA measurement of percentage of fat in the total body (Table 2). The highest relation $\left(\mathrm{R}^{2}\right)$ was for slice S4 in the shoulder region. The close relationship between the percentage of fat measured by DXA for the individual cross-sectional slices and the percentage of fat measured by DXA for the whole body is consistent with the results of DOORNENBAL (1972) comparing the amount of fat in several dissected crosssections throughout the carcass and total carcass fat $\left(\mathrm{R}^{2}\right.$ ranging from 0.94 to 0.98$)$ and the results of MITCHELL et al. (2002) comparing the DXA cross-sectional and DXA total fat analysis of pork half-carcasses ( $\mathrm{R}^{2}$ ranging from 0.91 to 0.98 ). 


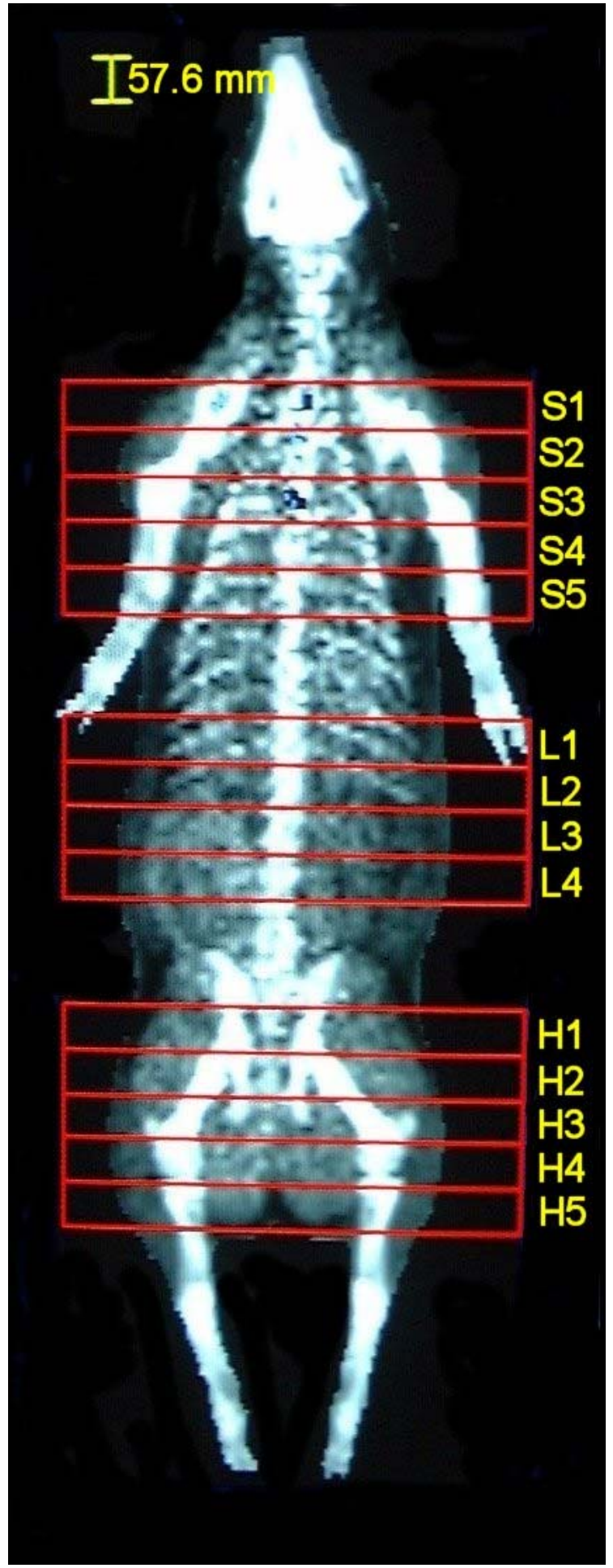

Fig. 1: Dual energy x-ray absorptiometry (DXA) scan of a pig showing the cross-sectional slices that were evaluated for predicting body composition (Dualenergie-Röntgenabsorptiometrie-Scan eines Schweines unter Darstellung der regional definierten Querschnitte zur Schätzung der Körperzusammensetzung)

The relationship between the DXA measurements of the percentage of fat in the soft tissue of cross-sectional slices and the chemical measurement of percentage of fat in the total body (determined by chemical analysis) is shown in Table 3. The coefficients of determination $\left(\mathrm{R}^{2}\right)$ ranged from 0.708 for $\mathrm{H} 5$ to 0.848 for $\mathrm{H} 2$, both in the ham region. The relationship between the fat measured by DXA for the cross-sectional 
slices and chemically determined percentage of total body compare favorably with the overall relationship for the measurement of percentage of fat in the total body based on the total body DXA scan (MITCHELL et al., 1996a).

Table 2

Regression analysis comparing dual energy x-ray absorptiometry (DXA) measurement of the percentage fat in the soft tissue of the total body (Y) to DXA measure of the percentage fat in the soft tissue of individual slices (X) using the linear model $\mathrm{Y}=\mathrm{a}+\mathrm{b} * \mathrm{X}$ (Regressions-Analyse zum Vergleich des prozentualen Fettgehaltes im Weichgewebe des gesamten Tierkörpers (Y) zu prozentualen Fettgehalts-Werten im Weichgewebe regional definierter Querschnitte (X) jeweils aus der Dualenergie-Röntgenabsorptiometrie [DXA] ) unter Verwendung des linearen Modells $\mathrm{Y}=\mathrm{a}+\mathrm{b} * \mathrm{X})$

\begin{tabular}{|c|c|c|c|c|}
\hline Slice location & Intercept (a) & Slope (b) & $\mathrm{R}^{2}$ & $\mathrm{SEE}^{\mathrm{a}}$ \\
\hline \multicolumn{5}{|c|}{ Front leg/Shoulder } \\
\hline $\mathrm{S} 1$ & 0.814 & 0.828 & 0.941 & 1.719 \\
\hline $\mathrm{S} 2$ & 1.608 & 0.835 & 0.942 & 1.705 \\
\hline S3 & 1.559 & 0.859 & 0.951 & 1.568 \\
\hline S4 & 1.901 & 0.895 & 0.966 & 1.305 \\
\hline S5 & 3.179 & 0.867 & 0.955 & 1.500 \\
\hline \multicolumn{5}{|l|}{ Abdomen } \\
\hline L1 & 4.464 & 0.960 & 0.933 & 1.835 \\
\hline L2 & 4.787 & 0.972 & 0.925 & 1.948 \\
\hline L3 & 5.363 & 0.972 & 0.914 & 2.087 \\
\hline L4 & 5.195 & 0.976 & 0.902 & 2.224 \\
\hline \multicolumn{5}{|l|}{ Back leg } \\
\hline H1 & 1.638 & 1.010 & 0.900 & 2.225 \\
\hline $\mathrm{H} 2$ & 2.974 & 1.005 & 0.882 & 2.418 \\
\hline H3 & 3.104 & 0.987 & 0.875 & 2.490 \\
\hline $\mathrm{H} 4$ & 2.155 & 1.065 & 0.849 & 2.730 \\
\hline $\mathrm{H} 5$ & 4.886 & 0.748 & 0.777 & 3.322 \\
\hline
\end{tabular}

${ }^{\mathrm{a}} \mathrm{SEE}=$ standard error of estimate.

Table 3

Regression analysis comparing chemical measurement of the percentage fat in the total body (Y) to the dual energy $\mathrm{x}$-ray absoptiometry (DXA) measure of the percentage fat in the soft tissue of individual slices (X) using the linear model $\mathrm{Y}=\mathrm{a}+\mathrm{b} * \mathrm{X}$ (Regressions-Analyse zum Vergleich des chemisch ermittelten Fettgehaltes (\%) im gesamten Tierkörper mit den prozentualen Fettgehalts-Werten im Weichgewebe regional definierter Querschnitte aus der Dualenergie-Röntgenabsorptiometrie [DXA] unter Verwendung des linearen Modells $\mathrm{Y}=$ $\mathrm{a}+\mathrm{b} * \mathrm{X})$

\begin{tabular}{|c|c|c|c|c|}
\hline Slice or region location & Intercept (a) & Slope (b) & $\mathrm{R}^{2}$ & $\mathrm{SEE}^{\mathrm{a}}$ \\
\hline \multicolumn{5}{|l|}{ Front leg/Shoulder } \\
\hline S1 & 7.010 & 0.683 & 0.844 & 2.361 \\
\hline $\mathrm{S} 2$ & 7.724 & 0.686 & 0.842 & 2.378 \\
\hline S3 & 7.750 & 0.703 & 0.841 & 2.385 \\
\hline S4 & 8.238 & 0.722 & 0.835 & 2.428 \\
\hline S5 & 9.185 & 0.703 & 0.838 & 2.402 \\
\hline \multicolumn{5}{|l|}{ Abdomen } \\
\hline L1 & 10.586 & 0.758 & 0.783 & 2.783 \\
\hline L2 & 10.882 & 0.765 & 0.771 & 2.859 \\
\hline L3 & 11.289 & 0.768 & 0.770 & 2.869 \\
\hline L4 & 11.361 & 0.757 & 0.736 & 3.070 \\
\hline \multicolumn{5}{|l|}{ Back leg } \\
\hline H1 & 7.102 & 0.863 & 0.841 & 2.387 \\
\hline $\mathrm{H} 2$ & 7.966 & 0.876 & 0.848 & 2.329 \\
\hline H3 & 8.250 & 0.849 & 0.842 & 2.379 \\
\hline $\mathrm{H} 4$ & 7.356 & 0.923 & 0.810 & 2.603 \\
\hline H5 & 10.044 & 0.632 & 0.708 & 3.231 \\
\hline
\end{tabular}


Typically, the percentage of protein in the live pig is difficult to predict accurately. Although statistically significant $(\mathrm{P}<0.001)$, the relationship between the DXA measurement of the percentage of lean in the soft tissue of the cross-sectional slices and the chemical measurement of percentage of protein in the whole body was much lower than observed for fat content. The coefficient of determination $\left(\mathrm{R}^{2}\right)$ between the percentage lean in DXA cross-sectional slices and the percentage protein in the total body ranged from 0.476 for $\mathrm{H} 5$ in the ham region to 0.601 for $\mathrm{H} 1$ in the ham region and 0.600 for S2 in the shoulder region (Table 4). In the study by DOORNENBAL (1971) it was shown that the chemically measured protein content of cross-sectional slices made at various locations throughout the length of the pork carcass were highly correlated with the total amount of protein in the entire half-carcass $\left(\mathrm{R}^{2}=0.78\right.$ to 0.95). From the data of SHIELDS and MAHAN (1983) there was a correlation $\left(\mathrm{R}^{2}\right)$ of $0.59(\mathrm{r}=0.77)$ between the amount of protein in the carcass and the amount of protein in the residue collected from sawing the carcass at $2.54 \mathrm{~cm}$ intervals in cross-section.

Table 4

Regression analysis comparing chemical measurement of the percentage protein in the total body ( $\mathrm{Y})$ to the DXA measure of the percentage lean in the soft tissue of individual slices $(\mathrm{X})$ using the linear model $\mathrm{Y}=\mathrm{a}+$ $\mathrm{b} * \mathrm{X}$ (Regressions-Analyse zum Vergleich des chemisch ermittelten Proteingehaltes (\%) im gesamten Tierkörper zu prozentualen Magergewebegehalts-Werten im Weichgewebe regional definierter Querschnitte aus der Dualenergie-Röntgenabsorptiometrie [DXA] unter Verwendung des linearen Modells $\mathrm{Y}=\mathrm{a}+\mathrm{b} * \mathrm{X}$ )

\begin{tabular}{lllll}
\hline Slice location & Intercept (a) & Slope (b) & $\mathrm{R}^{2}$ & SEE $^{\mathrm{a}}$ \\
\hline Front leg/Shoulder & & & & \\
S1 & 4.410 & 0.144 & 0.596 & 0.956 \\
S2 & 4.143 & 0.146 & 0.600 & 0.951 \\
S3 & 3.818 & 0.149 & 0.596 & 0.956 \\
S4 & 3.283 & 0.153 & 0.596 & 0.957 \\
S5 & 3.605 & 0.148 & 0.586 & 0.968 \\
Abdomen & & & & \\
L1 & 2.618 & 0.153 & 0.512 & 1.052 \\
L2 & 2.415 & 0.155 & 0.504 & 1.060 \\
L3 & 2.348 & 0.155 & 0.496 & 1.069 \\
L4 & 2.506 & 0.153 & 0.477 & \\
Back leg & & & & 0.955 \\
H1 & 0.503 & 0.183 & 0.601 & 0.987 \\
H2 & 0.576 & 0.180 & 0.574 & 0.989 \\
H3 & 0.985 & 0.175 & 0.572 & 1.043 \\
H4 & 0.050 & 0.185 & 0.524 & 1.094 \\
H5 & 5.133 & 0.130 & 0.476 &
\end{tabular}

The $\mathrm{R}^{2}$ for the relation between the DXA measurement of the percentage of lean in the soft tissue of the cross-sectional slices and the chemical measurement of percentage of water in the total body was slightly lower than observed for fat content. The coefficients of determination $\left(\mathrm{R}^{2}\right)$ ranged from 0.555 for $\mathrm{H} 5$ in the ham region to 0.755 for S5 in the shoulder region (Table 5). From the studies by SHIELDS and MAHAN (1983), the relationship between carcass water content and either the lean or water content of the sampled area was similar to the relationship between the fat content of the same components. However, in the present study the relationship between the water content of the total body and the lean content of the DXA cross-sectional slice could have been influenced by variation in water content of the intestinal tract. 
Table 5

Regression analysis comparing chemical measurement of the percentage water in the total body (Y) to the DXA measure of the percentage lean in the soft tissue of individual slices $(X)$ using the linear model $Y=a+b * X$ (Regressions-Analyse zum Vergleich des chemisch ermittelten Wassergehaltes (\%) im gesamten Tierkörper zu prozentualen Magergewebegehalts-Werten im Weichgewebe regional definierter Querschnitte) aus der Dualenergie-Röntgenabsorptiometrie [DXA] unter Verwendung des linearen Modells $\mathrm{Y}=\mathrm{a}+\mathrm{b} * \mathrm{X}$ )

\begin{tabular}{|c|c|c|c|c|}
\hline Slice location & Intercept (a) & Slope (b) & $\mathrm{R}^{2}$ & $\mathrm{SEE}^{\mathrm{a}}$ \\
\hline \multicolumn{5}{|c|}{ Front leg/Shoulder } \\
\hline $\mathrm{S} 1$ & 10.232 & 0.601 & 0.728 & 2.955 \\
\hline $\mathrm{S} 2$ & 9.170 & 0.606 & 0.731 & 2.936 \\
\hline S3 & 7.815 & 0.619 & 0.726 & 2.964 \\
\hline $\mathrm{S} 4$ & 4.797 & 0.648 & 0.749 & 2.840 \\
\hline S5 & 5.530 & 0.632 & 0.755 & 2.804 \\
\hline \multicolumn{5}{|l|}{ Abdomen } \\
\hline L1 & 0.579 & 0.666 & 0.677 & 3.222 \\
\hline L2 & -0.433 & 0.674 & 0.670 & 3.257 \\
\hline L3 & -1.408 & 0.681 & 0.675 & 3.232 \\
\hline L4 & -0.815 & 0.675 & 0.651 & 3.345 \\
\hline \multicolumn{5}{|l|}{ Back leg } \\
\hline H1 & -5.419 & 0.757 & 0.725 & 2.980 \\
\hline $\mathrm{H} 2$ & -5.579 & 0.747 & 0.703 & 3.097 \\
\hline H3 & -3.526 & 0.724 & 0.694 & 3.146 \\
\hline H4 & -8.051 & 0.775 & 0.648 & 3.372 \\
\hline H5 & 14.501 & 0.525 & 0.555 & 3.790 \\
\hline
\end{tabular}

${ }^{\mathrm{a}} \mathrm{SEE}=$ standard error of estimate.

Table 6

Prediction equations for the estimation of percentage of fat and lean in the total body using dual energy x-ray absorptiometry (DXA) (Regressionsgleichungen für die Schätzung von Fett- und Magergewebegehalt (\%) des gesamten Tierkörpers unter Verwendung der Dualenergie-Röntgenabsorptiometrie - DXA)

Estimation of percentage fat in total body

DXA scan of entire body:

FAT $\%=6.5+(0.817 \times$ DXA fat $\%)$

FAT $\%=566-(402 \times$ DXA R value $)$

$\left(\mathrm{R}^{2}=0.88, \mathrm{SEE}=2.06\right)$

$\left(\mathrm{R}^{2}=0.88, \mathrm{SEE}=2.02\right)$

Single DXA cross-sectional slice:

FAT $\%=7.96+(0.876 \times$ H2 fat $\%)$

$\left(\mathrm{R}^{2}=0.85, \mathrm{SEE}=2.33\right)$

Combination of three DXA slices:

FAT $\%=6.9+(0.26 \times$ S1 fat $\%)+$

$(0.14 \times \mathrm{L} 1 \mathrm{fat} \%)+(0.44 \times \mathrm{H} 2 \mathrm{fat} \%) \quad\left(\mathrm{R}^{2}=0.89, \mathrm{SEE}=1.96\right)$

Estimation of percentage lean in total body

DXA scan of entire body:

LEAN \% $=2.37+(0.886 \times$ DXA lean\%)

$\left(\mathrm{R}^{2}=0.79, \mathrm{SEE}=2.07\right)$

LEAN \% $=-506+(428 \times$ DXA R value $)$

$\left(\mathrm{R}^{2}=0.81, \mathrm{SEE}=1.97\right)$

Single DXA cross-sectional slice:

LEAN \% = -7.8 + (0.96 x H2 lean\%)

$\left(\mathrm{R}^{2}=0.82, \mathrm{SEE}=2.59\right)$

Combination of three DXA slices:

LEAN \% $=-4.7+(0.58 \times$ H2 lean\% $)+$ $(0.217$ x S2 lean\% $)+(0.135$ x L1 lean\%)

$\left(\mathrm{R}^{2}=0.84, \mathrm{SEE}=2.59\right)$

Based on the relationships between chemical analysis of the total body and DXA results, equations were developed for predicting the percentages of fat or lean in the total body using either the DXA information from the total body, a single slice (H2), or a combination of three slices (H2, S2, and L1). These locations were chosen based on their high $\mathrm{R}^{2}$ with several parameters. These prediction equations are presented in 
Table 6. Using the DXA scan of the entire body, the regression equation for the prediction of percentage fat is somewhat different from that reported previously (MITCHELL et al., 1996a), however, the regression coefficient $\left(\mathrm{R}^{2}=0.88\right)$ is similar to that reported by MITCHELL et al. (1997). The $\mathrm{R}^{2}$ for the prediction based on analysis of a single slice (H2) was only slightly lower than that based on a total body scan and was improved very little by the inclusion of two additional slices. The relationship between the percentage of total body fat predicted from the percent fat in $\mathrm{H} 2$ and the percentage of fat observed by chemical analysis is shown in Figure 2. In this figure a single out-lier can be observed (18\% fat predicted vs. 28\% fat observed). A regional analysis of the DXA scan of this pig revealed an abnormal fat distribution a much higher fat content in the shoulder region relative to the ham region than was observed in other pigs. Thus, this is an example of how in a large population of pigs (of different genotypes, breeds or cross-bred lines) there are likely to be some individuals where the prediction of total body fat based on this "single slice" approach would yield inaccurate results. Breed or line specific equations might be necessary in this case.

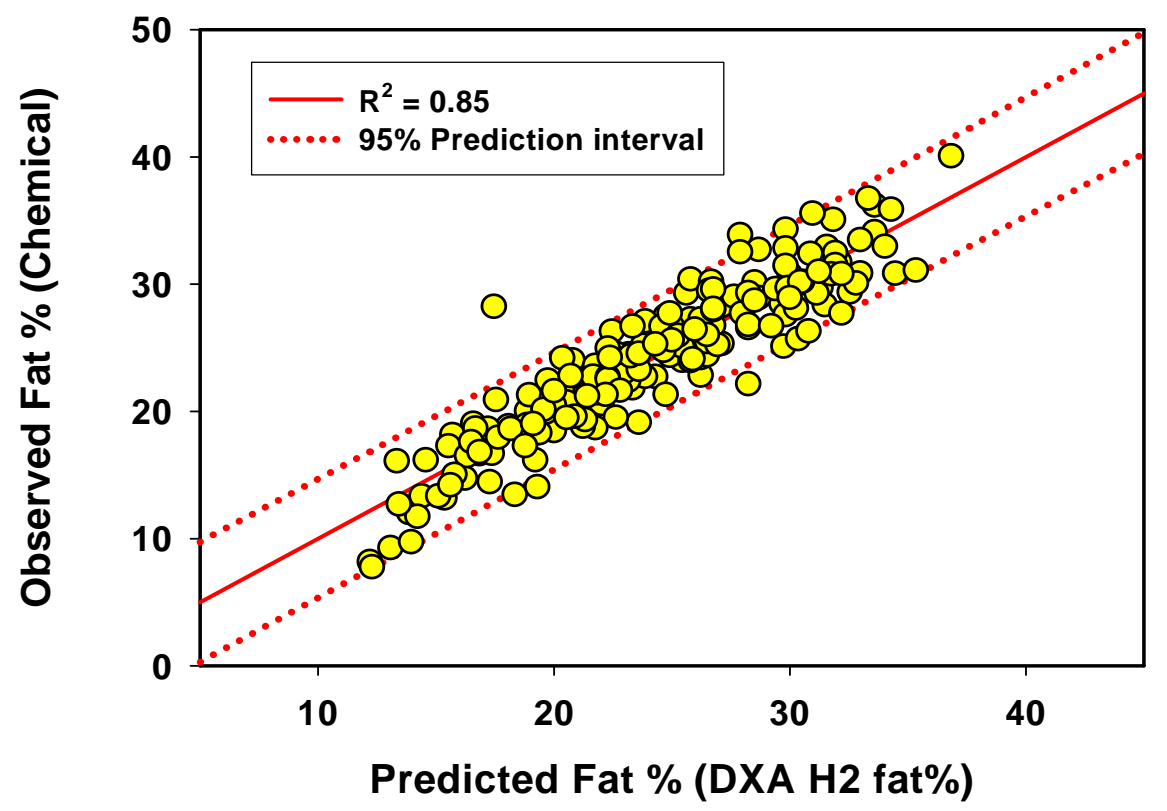

Fig. 2: Prediction of total body fat content using a single slice (H2) of a dual energy x-ray absioptiometry (DXA) scan (Schätzung des Gesamtkörper-Fettgehaltes (\%) unter Verwendung eines einzelnen Querschnitts [H2] aus der Dualenergie-Röntgenabsorptiometrie-DXA)

The regression coefficient $\left(\mathrm{R}^{2}\right)$ for the DXA prediction of total body lean, using either the total body scan or cross-sectional slices, was lower than that for the prediction of total body fat. Contributing to the lower $\mathrm{R}^{2}$ is the chemical estimate of the percentage of total body lean itself that consists of the combined measurements of total body water and total body protein. The $\mathrm{R}^{2}$ for the prediction using the DXA lean content of the single cross-sectional slice (H2) was slightly higher than that based on the total body scan and increased only slightly with the inclusion of two additional slices (S2 
and L1). A plot of the relationship between observed and DXA-H2 predicted values for percentage of total body lean is shown in Figure 3.

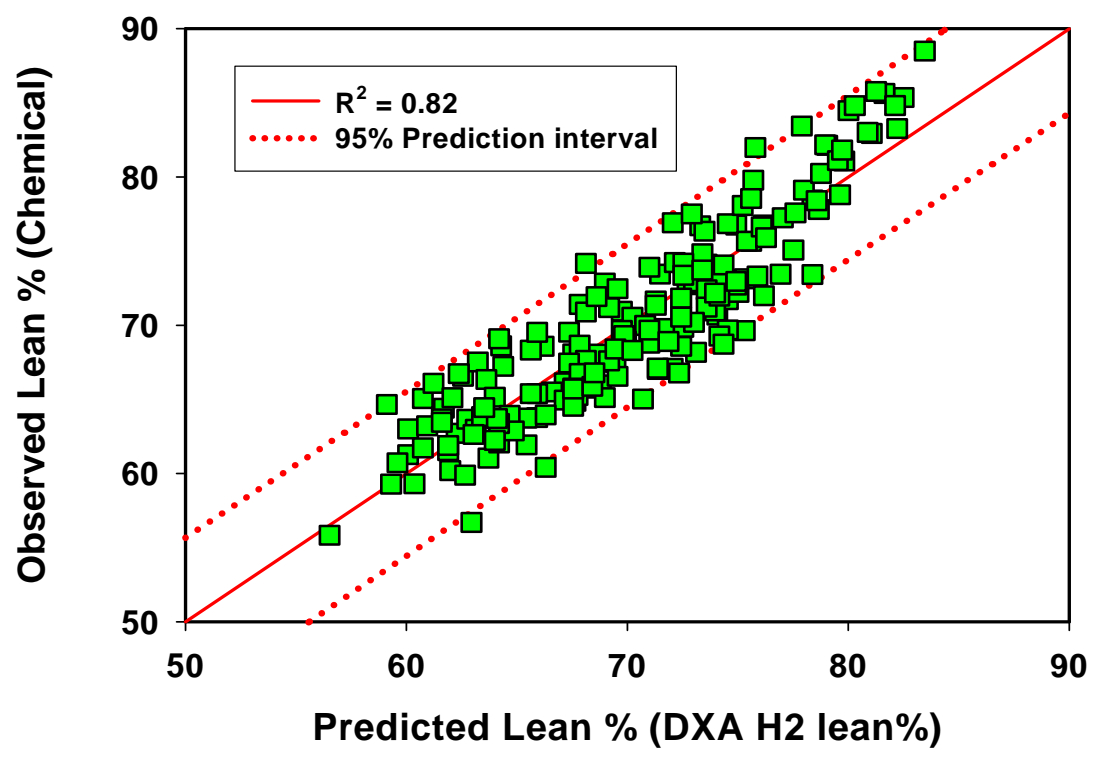

Fig. 3: Prediction of total body lean content using a single slice (H2) of a dual energy x-ray absioptiometry (DXA) scan (Schätzung des Gesamtkörper-Magergewebegehaltes (\%) unter Verwendung eines einzelnen Querschnitts [H2] aus der Dualenergie-Röntgenabsorptiometrie-DXA)

In general, the lowest correlations were found in the abdominal region (L1-L4), where variation in gut fill may have been a factor. Furthermore, the possible variation in gut fill may have contributed to the lower $\mathrm{R}^{2}$ values for the relationship between DXA lean and total body water or chemical lean than were observed for DXA slices of the pork carcass (MITCHELL et al., 2002). The low correlations for H5 (last slice in the back leg region) are probably due to location variation resulting from the range in body size. For smaller pigs this slice was located in the more distal portion of the back leg, thus including variable portions of the ham muscles. In conclusion, these results indicate that a single DXA cross-sectional scan (or combination single scans) can be used to predict total body composition of the pig.

The implication of these results is that DXA could possibly be adapted whereby pigs could be scanned with minimal restraint and resulting in a cross-sectional sample that could be used to predict total body composition. In all of the scans analyzed in this study the pig was in a prone position with the legs extended parallel to the body. Thus, analysis based on a cross-sectional scan obtained with the pig in a standing position would likely require additional calibration.

\section{References}

AOAC:

Methods of Analysis. 14 ${ }^{\text {th }}$ ed. Association of Official Analytical Chemists, (1984) Washington, DC BAULAIN, U.; HENNING, M.; KALLWEIT, E.:

Bestimmung der Körperzusammensetzung von Landrasse-Schweinen unterschiedlichen Alters mittels MRI. (Determination of body composition in German Landrace pigs of various ages by means of MRI). Arch. Tierz., Dummerstorf 39 (1996), 431-440 
BRANSCHEID, W.; DOBROWOLSKI, A.; HÖRETH, R.:

Die Video-Image-Analyse: Methode zur On-line-Erfassung des Teilstückwertes von Schweineschlachtkörpern. Fleischwirtschaft 75 (1995), 636-642

DOORNENBAL, H.:

Growth, development and chemical composition of the pig I. Lean tissue and protein. Growth 35 (1971), 281-295

DOORNENBAL, H.:

Growth, development and chemical composition of the pig II. Fatty tissue and chemical fat. Growth 36 (1972), 185-194

FOLCH, J. M.; LEES, M.; SLOAN-STANLEY, G. H.

A simple method for the isolation and purification of total lipids from animal tissues. J. Biol. Chem. 226 (1957), 497-509

FOWLER, P. A.; FULLER, M. F.; GLASBEY, C. A.; CAMERON, G. G.; FOSTER, M. A.:

Validation of the in vivo measurement of adipose tissue by magnetic resonance imaging of lean and obese pigs. Am. J. Clin. Nutr. 56 (1992), 7-13

HORN, P.; KÖVÉR, Gy.; REPA, I.; BERÉNYI, E.; KOVÁCH, G.:

The use of spiral CAT for volumetric estimation of body composition of pigs. Arch. Tierz., Dummerstorf 40 (1997), 445-450

MITCHELL, A. D.; CONWAY, J. M.; POTTS, W. J. E.:

Body composition analysis of pigs by dual-energy x-ray absorptiometry . J. Anim. Sci. 74 (1996a), 2663-2671

MITCHELL, A. D.; CONWAY, J. M.; SCHOLZ, A. M.:

Incremental changes in total and regional body composition of growing pigs measured by dual-energy x-ray absorptiometry. Growth, Dev. Aging. 60 (1996b), 95-105

MITCHELL, A. D.; SCHOLZ, A. M.:

Dual-energy x-ray absorptiometry (DXA) analysis of growth and body composition of pigs of different ryanodine receptor genotypes. Arch. Tierz., Dummerstorf 40 (1997), 11-21

MITCHELL, A. D.; SCHOLZ, A.M.; CONWAY, J.M.:

Body composition analysis of small pigs by dual-energy x-ray absorptiometry. J. Anim. Sci. 76 (1998), 2392-2398.

MITCHELL, A.D.; SCHOLZ, A.M.; WANG, P.C.; SONG, H.:

Body composition analysis of the pig by magnetic resonance imaging. J. Anim. Sci. 79 (2001), 18001813

MITCHELL, A. D.; SCHOLZ, A. M.; PURSEL, V. G.:

Prediction of pork carcass composition based on cross-sectional region analysis of dual energy X-ray absorptiometry (DXA) scanning. Meat Sci. (2002), (in press)

NORD, R. H.; HOMUTH, J. R.; HANSON, J. A.; MAZESS, R. B.:

Evaluation of a new DXA fan-beam instrument for measuring body composition. Ann. New York Acad. Sci. 904 (2000), 118-125

SHIELDS, R. G., JR.; MAHAN, D. C.:

Evaluation of ground carcass, sawdust residue and specific gravity methods for estimating body composition of reproducing swine. J. Anim. Sci. 57 (1983), 604-608

SZABO, CS.; BABINSZKY, L.; VERSTEGEN, M.W.A.; VANGEN, O.; JANSMAN, A.J.M.; KANIS, E.:

The application of digital imaging techniques in the in vivo estimation of the body composition of pigs: a review. Livest. Prod. Sci. 60 (1999), 1-11

Received: 2002-08-02

Authors' addresses

Dr. ALVA D. MITCHELL

United States Department of Agriculture

Growth Biology Laboratory

Beltsville, MD 20705, USA

E-Mail: Mitchell@anri.barc.usda.gov

Dr. VERNON PURSEL

United States Department of Agriculture

Agricultural Research Service

Gene Evaluation and Mapping Laboratory

Beltsville, MD 20705, USA

Accepted: 2002-09-24

Dr. ARMIN M. SCHOLZ

Lehr- und Versuchsgut Oberschleißheim der Tierärztlichen Fakultät der

Ludwig-Maximilians-Univ. München

Hubertusstr. 12

D-85764 Oberschleißheim, Germany 